\title{
ANTINARCOTIC TESTING IN CALIFORNIA: OF SUBSTANTIVE DUE PROCESS
}

\author{
So leap with joy, be blithe and gay \\ Or weep my friends, with sorrow. \\ What California is today, \\ The rest will be tomorrow.
}

Richard Armour

In California, it is a felony to possess narcotics without the prescription of a licensed doctor, dentist, podiatrist or veterinarian. The penalty for such possession is imprisonment in the state prison for not less than two years nor more than ten years. ${ }^{1}$ Furthermore, it is a misdemeanor, punishable by a term of ninety days to one year in the county jail, to use or be under the influence of narcotics. ${ }^{2}$

Unfortunately, penal sanctions alone have not been sufficient to curb the use of narcotics in California. The continual increase of narcotics addiction has become alarming to those who are concerned with the degradation and waste of human potential that so often accompanies it. ${ }^{3}$ A concern of equal, if not greater, intensity is shared by the general public and law enforcement officials throughout the state, and, indeed, throughout the nation as a whole. ${ }^{4}$ This latter concern is not only a concern for the addict himself, but also for the additional burdens the addict and his habit place upon society at large. It is almost axiomatic that a rise in narcotics addiction is accompanied by an increase in petty thefts and burglaries needed to support sucl a habit and an increase in organized crime syndicates which supply the addict with his illegal drugs. ${ }^{5}$

In response to this growing problem, the state of California has developed a program of antinarcotic testing to determine whether a person is using narcotics. The purpose of such a test is reflected in California Health and Safety Code section 11728:

1 CaI. Hearth \& Safety Code \& 11500 (West 1964). The punishment for a second violation of this section is 5-20 years, and for a third violation it is 15 years to life. In all cases parole is not available until at least the minimum term has been served.

2 CAL. HeALIT \& SAFETY CODE § 11721 (West 1964). Until 1962 it was a violation under this section to be addicted to narcotics. See Robinson v. California, 370 U.S. 660 (1962).

3 A prime example of this concern is reflected in the Synanon organization and by its founder Charles E. Dederich. See generally I. Yablonskz, The Tunnez Back: Synanow (1965); D. CaSrIer, So Fatr a House (1963).

4 Paper presented by Lt. Brown, Oakland Police Department, Joint Meeting of the Northern-Central California Narcotics Officers' Association with Southern California Narcotics Officers, Oct. 29, 1959. "Narcotics addicts are estimated to be responsible for one-half the crimes committed in New York City alone. . ." Ch. 192, § 200, [1966] N.Y. Laws 198.

5 Cartfornta Bureau of Narcotic Enforcenient, The Narcotic Probrem 15 (1965). D. Matrer \& V. Voger, Narcotics and Narcotics Addiction 210-11 (1954). 
The rehabilitation of narcotics addicts and the prevention of continued addiction to narcotics is a matter of statewide concern. It is the policy of this State to encourage ... testing procedures to determine narcotic addiction ... and to foster research in means of detecting the existence of narcotic addiction ....

Such a test provides law enforcement officials with a positive means of proving use or addiction, and, more importantly, provides a means of controlling narcotics use of known addicts and users by regularly testing them.

This Comment is concerned with the constitutionality and efficacy of using a "synthetic opiate antinarcotic in action," or "Nalline" test to control the use of narcotics in California. Specifically, it is concerned with the effects of Nalline testing on parolees under the supervision of the California Department of Corrections, as authorized by the Health and Safety Code section 11722. This section states that the Adult Authority, in considering for parole any person who is or has been a user of narcotics, may condition parole on his voluntary submission to periodic tests to determine whether he is a narcotic addict.?

The Comment is divided into three parts. Part I examines the Nalline test itself, the drugs used in the test, the procedure followed, the test's reliabihity, and its effect upon those who submit to it. Part II explores the relevant constitutional objections to the test-specifically, the fifth amendment's protection against self-incrimination, the eiglith amendment's protection against cruel and unusual punislment,' and the fourteenth amendment's guarantee of substantive due process. Part III analyzes the policy considerations relevant to continuance of the Nalline testing procedure. The Comment concludes that even if Nalline is constitutionally permissible, it is self-defeating and should be eliminated.

\section{I}

THE NALLINE T'EST

When the legislature stated its policy in favor of using a "synthetic opiate antinarcotic in action" to detect the use of narcotics, it did not specify that the synthetic opiate antinarcotic should be Nalline. However, it appears that the legislature had Nalline in mind when it enacted Health and Welfare Code sections 11722, 11723 and 11728.

Nalline is the trade name for $\mathrm{N}$-allynormorphine (nalorphine hydro-

6 See text accompanying footnote 9 infra.

7 Cat. Health \& Safety Code $\S 11722$ (c) (West 1964). Nalline is also used to test any person arrested for a criminal offence and suspected of being a narcotic addict. Cax. Heartri \& SAFETy CODE § 11723 (West 1964).

8 See People v. Williams, 164 Cal. App. 2d 858, 862, 331 P.2d 251, 254 (1958). 
chloride). It is antagonistic to, and will detect the use of, morphine, methadone, opium, heroin, Dilaudid, Dromoran, dihydromorphine, methorphinan, and all related compounds. ${ }^{9}$ There is doubt, however, as to the value of Nalline in detecting meperidine hydrochloride (Demerol) ${ }^{10}$ and codeine $^{11}$; Nalline will not produce an effect on persons using cocaine, marijuana and barbiturates. ${ }^{12}$

Historically, Nalline has been used for three distinct purposes: (1) to prevent and treat respiratory depression in the newborn; (2) to treat narcotics poisoning; and (3) to diagnose a physical dependence (addiction) on narcotics. ${ }^{13}$ Recently ${ }^{14}$ a fourth use of Nalline has been developed, that of detecting the presence of narcotics within an individual's system. The recommended test $t^{15}$ for the presence of narcotics is fairly simple. First, a medical history is obtained from the patient to determine whether the Nalline test is contraindicated. ${ }^{16}$ Possible contraindications include any severe organic disease and pregnancy. Injection of Nalline into any person who has a severe organic disease may cause a reaction to the drug resulting possibly in death; the introduction of Nalline into a pregnant woman may induce abortion, especially in the last trimester. The subject should receive at least a cursory physical examination, primarily by inspection for needlemarks, to determine whether he has recently used narcotics. If recent use is obvious or admitted, the test should be abandoned, as it may have adverse physical effects on the patient, at least sufficient to cause unnecessary discomfort.

Assuming the test is in no way contraindicated, the patient is seated in a dentist's-type chair in a room where light intensity is controlled, and a licensed doctor ${ }^{17}$ measures the dilation of the patient's pupils with a

- See Roth, Poisonings, in Tye Medical Clinics of North America 199, 203 (Jan. 1954) [hereinafted cited as Roth]; cf. 154 J.A.M.A. 414 (1954); R. CECII \& R. LOEB, A Texibooz of Medicine 1637 (10th ed. 1959). See generally Fraser, Human Pharmacology and Clinical Uses of Nalorphine, in The Medical Cinnics of Nortr AMrerica 393 (Mar. 1957) [hereinafter cited as Fraser].

10 See 154 J.A.M.A. 414 (1954). But see Fraser, supra note 9, at 399.

11 Perystcians' Desk Reference to Phararaceutical Spectatites and Biologicals 762 (17th ed. 1963).

12 See Roth, supra note 9, at 203.

13 See Terry \& Braumoeller, Nalline: An Aid in Detecting Narcotic Users, 85 Car. MedicnNe 299 (1956) [hereinafter cited as Terry and Braumoeller].

14 Between 1950 and 1952 the United States Public Health Service in Lexington, Kentucky, experimented with the use of Nalline for this purpose.

15 Catifornta Dep't of Pub. Healte, Recomalended Procedure for Narcotic Use Testing of Probattoners and Parolees (1961) [hereinafter cited as Recommarnded ProCEDURES].

$10 I d$. at 4.

17 See 17 Cax. ADMr. CODE $\$ 2710$ (West 1964). 
pupilometer. ${ }^{18} \mathrm{~A}$ Nalline solution of three miligrams is then injected into the arm, immediately under the skin. Approximately thirty minutes later, the pupils are measured again. If the patient has not been using any of the narcotics whicl are susceptible to the Nalline test, his pupils will contract. If there is no change in pupil dilation, the test is deemed equivocal (does not indicate use or abstinence), and a more accurate urine test is usually performed. ${ }^{19}$ If the pupils dilate, it is an indication of use of or even addiction to narcotics.

Pupillary response to the Nalline test has been found to be an accurate imdex of addiction, occasional use and abstinence. ${ }^{20}$ In the past, the American Medical Association disagreed with the above procedure. It suggested in some cases that sixteen rather than three milligrams of $\mathrm{Nal}-$ line be admimistered to the patient. If the patient laad recently used narcotics, side effects such as perspiration, nausea, defecation, yawning, gooseflesh, running nose, and tearing eyes would be produced..$^{21}$ At the same time, however, the AMA warned that "the use of Nalline... is not an innocous procedure, since too large a dose... will produce symptoms severe enougli to endanger the lives of persons strongly addicted to these drugs." ${ }^{22}$ After extensive testing of the three milligram dose, the Califorma Department of Public Health concluded that pupillary response was sufficient to detect use and that it would not be necessary to produce the withdrawal symptoms originally recommended by the AMA. ${ }^{23}$

There seems to be hittle doubt as to the rehiability of the Nalline test if it is properly admimistered. ${ }^{24}$ Since 1958 , extensive tests have been conducted in this regard. The conclusion of these tests is that "the pupillary test with [Nalline] is a useful tool for determiming whether an individual is a narcotics user...."25

The criticism of Nalline is not related to its reliability, but rather to its effects on the persons who are tested and to the test's inherent dan-

18 See Recomomended Procedures, supra note 15 , at 12.

19 See text accompanying notes 77-79 infra.

20 See Terry \& Braumoeller, supra note 13 , at 300.

21 See 154 J.A.M.A. 414 (1954).

22 Id.

23 See Recomarended Procedures, supre note 15 , at 5.

24 Interview with Dr. James Terry, Medical Officer for Santa Rita Rehabilitation Center, Alameda County, Cal. and physician at the Alameda County Nalline Clinic, at the Alameda County Health Department, Aug. 7, 1967. It has been Dr. Terry's experience over the past 8-10 years that when the Nalline test indicates a positive result it is accurate. He is able to test his results because probation officers and parole agents usually obtain a urine test at that time to determine exactly what drugs are being used.

25 Calffornia Dep't of Justice, a Report on the Syntaltic Opiate ANti-Narcotic Testing Prograds 12 (1961). 
gers. Whether or not an individual is using drugs, he may still have a reaction to Nalline itself.

Small doses of nalorphine have been reported to produce pleasant relaxation and drowsiness, a sense of well-being and buoyancy, a sense of ill-being and dissatisfaction, day-dreams, constriction of the pupil of the eyes, nausea, giddiness, sweating, inability to coordinate voluntary muscular movements, drooping of the eyelids and vomiting. ${ }^{26}$

Nalline has become the predominant method of controlling narcotics within the Parole System in California; inherent in such a test is unnecessary discomfort, if not actual physical danger. Therefore, it is desirable to examine the possibility that such a test violates gurantees provided by the United States Constitution.

II

CONSTITUTIONAL OBJECTIONS TO THE NALLINE TEST

The first and only constitutional attack on the Nalline test was in People v. Zavala. ${ }^{27}$ The defendant contended that the use of the results of a Nalline test in court, without his consent, violated the privilege against self-incrimination. The court ruled the evidence was inadmissible on the grounds that Health and Safety Code section 11723 required written consent by the defendant in order to administer the Nalline test. Since this was not done, the test was not admissible. However, the court further stated that had the statute not required writted consent, the test would be admissible because the privilege against self-incrimination only applies to testinionial compulsion. ${ }^{28}$ The introduction of Nalline results into evidence would be analgous to the admissibility of blood tests or fingerprints. ${ }^{29}$ Since Health and Safety Code section 11722, unlike section 11723 , gives the parole division the authority to require parolees to submit to Nalline testing as a condition of parole without requiring his consent, it seems clear that the results of such a test would be admissible.

However, due to the structure of the parole system, the above discussion is highly academic. Even if the courts were to read into section 11722 a requirement of consent, it would be of little benefit to the parolee. The parole division does not use the Nalline test to gather information for the purpose of obtaining new narcotics convictions; its purpose is to

26 Id. at 10.

27239 Cal. App. 2 d 732, 49 Cal. Rptr. 129 (1966).

28 See 8 J. WigMORE, Evidence $\$ \S 2263,2265$ (J. McNaughton ed. 1961); Schmerber v. California, 384 U.S. 757 (1966). For a general discussion of self-incrimination see F. Inbad, Self-Incrimmation: What Can an Accused Person Be Comapelted To Do 3-8, 87 (1950).

20 People v. Zavala, 239 Cal. App. 2d 732, 737-38, 49 Cal. Rptr. 129, 133-34 (1966). 
detect violations of the conditions of parole. ${ }^{30}$ If the Nalline test indicated use, the parolee could be returned to prison on the ground that he violated a condition of parole by returning to the use of narcotics. Even if the results of the Nalline test were not admissible in the "hearing" to determine parole violation, the parolee would not be protected because if the parole agent was convinced of the parolee's use of narcotics, he could have the parolee returned to prison on a nebulous teclinical violation of parole (sucl as "not being cooperative with the agent").

The second constitutional objection to Nalline is that it violates the eighth amendment's protection against cruel and unusual punishment. Robinson v. California ${ }^{31}$ held it unconstitutional to punish addiction because addiction is not a crime, but an illness. In People v. Zapata $a^{32}$ the defendant was convicted of possession of narcotics used to support his own habit. His contention was that the law was, in effect, punishing him for his addiction. The court in Zapata rejected this contention. It limited the Robinson case to the holding that it is cruel and unusual punishment to convict someone of a crime where the offense consisted merely of being in the state of California wlile addicted to narcotics. The court further held that it was within the state's power to impose criminal sanctions against unauthorized manufacture, prescription, sale, purchase, use or possession of narcotics. ${ }^{33}$ This latter argument controverts the contention that because Nalline is a test to determine addiction, and because addiction is not illegal, such a test serves no state interest. Since it can be argued that Nalline detects the use of narcotics, thereby proving illegal possession, the Zapata court could find the Nalline test was valid under the criteria set forth in Robinson. In fact, the Zapata court stated that the Robinson decision could be viewed "as a constitutionally inspired deinand for treatment-oriented programs,"34 and that the Nalline Testing Procedure authorized by Health and Safety Code section 11722 was such a "program."

However, even if the Robinson decision was an inspired demand for treatment-oriented programs, it certainly did not protect programs which fail to provide the due process safeguards required under the constitution. Even People v. Zavala ${ }^{38}$ recognized that Nalline must meet these standards to become constitutionally permissible. The court there stated

30 Interview with Gene Lutrell, Acting Parole Administrator for the Oakland Parole District, in Oakland, July 17, 1967.

31370 U.S. 660 (1962).

32220 Cal. App. 2d 903, 34 Cal. Rptr. 171 (1963).

33 Id. at 907, 34 Cal. Rptr. at 174.

34 Id. at 906, 34 Cal. Rptr. at 174.

35 Id. at 906 n.4, 34 Cal. Rptr. at 174 n.4.

36239 Cal. App. 2d 732, 49 Cal. Rptr. 129 (1966). 
that "a person has no constitutional right to refuse to take a Nalline test provided it is administered in a medically approved nuanner and not in a fashion that shocks the conscience or offends one's sense of justice." ${ }^{\prime 37}$

The "shock the conscience" test is quite imprecise, being subject, almost entirely, to the visceral impulses of those justices who preside over the specific case. In Rochin v. Californi $a^{38}$ the Court found that it violated the due process clause of the fourteenth amendment to pump a defendant's stomach against his will to obtain morphine capsules he had swallowed. The Court stated that such police conduct offended "those canons of decency and fairness which express notions of justice of English-speaking peoples even towards those charged with the most heinous offenses." 30

Later, in Irvine v. California, ${ }^{40}$ the Court upheld the admissibility of evidence obtained by "bugging" the defendant's bedroon and closet. The Court castigated the police for their misconduct, but refused to apply the due process standard of Rochin. The Court held that the Rochin doctrine applied only to situations involving coercion, violence, or brutality to the person. Similarly, Breithaupt v. Abram ${ }^{41}$ failed to find Rochin-type coercion or brutality, and held that it was constitutional for the police to take a blood sample from an unconscious person who had been involved in an automobile collision to determine whether the defendant was intoxicated. Justice Clark, writing for the majority, stressed that the sample of blood was taken under the protective eye of a physician and that "the blood test procedure has become routine in our everyday life." 42 The naajority in Breithaupt made it quite clear that the Court would only be shocked if the state's interest in discovering intoxication was outweiglied by the defendant's interest in not being so treated. Justice Clark pointed out that "as against the right of an individual that his person be held inviolable, even against so shight an intrusion as involved in applying a blood test of the kind to which millions of Americans submit as a matter of course nearly every day, must be set the interests of society in the scientific determination of intoxication, one of the great causes of mortal hazards of the road." ${ }^{33}$ Given the conclusion of the majority in Breithaupt,

37 Id. at 739, 49 Cal. Rptr. at 134.

38342 U.S. 165 (1954).

38 Id. at 169 .

40347 U.S. 128 (1954).

41352 U.S. 432 (1957).

42 Id. at 436. See also id, at 437-38.

43 Id. at 439 . The Supreme Court reaffirmed the Breithaupt standards in Schmerber v. California, 384 U.S. 757 (1966). The Court held that a blood test taken to determine intoxication did not shock its conscience in spite of the fact that the test was taken against the will of the defendant. 
the determination of substantive due process is a matter of balancing interests.

Upon examination of these cases, it is apparent that if Robinson was a plea for treatment-oriented programs as the Zapata court intimated, it was a plea for only those programs which could withstand the scrutiny of the substantive due process balancing test elucidated in Breithanpt. In fact, such a standard may be imphicit in the Robinson decision itself. There is language in Robinson to indicate that the court intended the cruel and unusual punishment clause to serve as a substantive due process test, subjecting federal and state criminal laws to continuing reappraisal in light of current standards. Justice Stewart, writing for the majority in Robinson, stated that where criminal law is the means of regulation, a law which "in light of contemporary human knowledge" is both unusual and unfair is cruel and unusual punishment. ${ }^{44}$ Indeed the law need not even be unusual, for when the Robinson case reached the Supreme Court, eighteen states and the District of Columbia had laws penalizing addiction. ${ }^{45}$

It seemed clear, at least to Justice White who dissented in Robinson, that the Court was using the cruel and unusual punishment clause to evoke a test of substantive due process. Justice White commented that "if [the Robinson case] involved economic regulation, the present Court's allergy to substantive due process would surely save the statute." ${ }^{10}$ The substantive nature of the Court's ruling is further illustrated by the brief for Robinson, which argued the unreasonableness of the California statute in relation to a violation of equal protection. ${ }^{47}$ Very little of the brief discussed cruel and unusual punishment, ${ }^{48}$ and it did not suggest that to punish addiction was cruel and unusual punishment. The Court apparently envisioned the eiglith amendment as a new means to strike down state criminal legislation which violated the essence of ordered hiberty. ${ }^{49}$ Robinson reaffirmed the Court's role of deciding constitutionality on the basis of wliat does or does not "shock the conscience."

For the purpose of this Comment, it can be assumed that the Nalline test, as applied to freely consenting persons tested under Health and Safety Code section 11723 , does not violate any substantive due process provision of the Constitution, because there is no coercion on the part of

44370 U.S. 660,666 (1962).

45 See W. ELDRIDGE, NARCOTICS AND tHE LAW 149-87 (1962).

40370 U.S. 660,689 (1962).

47 Brief for Petitioner at 13, Robinson v. California, 370 U.S. 660 (1962).

48 Id. at 29-30.

49 Palko v. Connecticut, 302 U.S. 319, 325 (1937).

50 See Snyder v. Massachusetts, 291 U.S. 97 (1934). 
the state; such persons can protect their rights by refusing to consent to the test.

This consent protection, however, is not available to parolees who are required to submit to Nalline under section 11722 . Therefore, in order to determine whether Nalline testing for parolees violates the substantive due process provision of the fourteenth amendment as defined in Breithaupt or the substantive provision of the eighth amendment's protection against cruel and unusual punishment as suggested by the Robinson case $^{51}$, it will be necessary to examine both California's interest in requiring the test and the parolees' interest in having such a test abolished.

It cannot be demied that the state has a strong interest in controlling the use of narcotics. Health and Safety Code section 11500 provides criminal penalties for use, possession or sale of narcotics. This section embodies the state's interest in narcotics control through the use of the traditional means of law enforcement. However, the state's interest in controlling narcotics through the use of Nalline is not quite so pervasive. Health and Safety Code section 11728 clearly states that the purpose of antinarcotic testing is to prevent continued addiction and to rehabilitate narcotics addicts. Its purpose is not to punish those who do use narcotics. Therefore, although the state interest in narcotics control cannot be denied, it may be demied that the state, in order to pursue its objectives, may subject parolees to unnecessary physical and mental ordeals coincident with the use of Nalline. ${ }^{52}$

Proponents of Nalline testing claim that the Nalline injection is analogous to the taking of a blood test, and as such should be upheld on the strength of the Breithaupt decision. The analogy is too superficial. To be sure, as in Breithaupt, the test is performed under the "protective eye" of a physician, but here the comparison ends. Nalline, unlike a blood test, is not a commonplace event. It is not part of our "routine, everyday" lives, and it is not innocuous even if performed correctly. Unlike blood tests, which present no danger to the subject when properly performed, Nalline may present a considerable hazard. Doctors admit that some of those who take the test may have adverse reactions, ranging from mild sickness to

51 See text accompanying notes 46-50 supra.

52 The suggestion that parolees do not have the constitutional protection against cruel and unusual punishment is not well founded. If the Department of Corrections decided to sterilize a prisoner as punishment for using narcotics, he would be able to enjoin the department from so acting. See Skinner v. Oklahoma, 316 U.S. 535 (1942). Certainly such action under today's standards would be cruel and unusual punishment. If the Parole Division should attempt the same thing while the man is on parole or make such action a condition of parole, he would still have the same right to stop this as he did in prison. See People v. Hernandez, 229 Cal. App. 2d 143, 40 Cal. Rptr. 100 (1964). 
severe shock. ${ }^{53}$ It is impossible to determine beforehand which parolees will have reactions; the fact that a parolee experiences no reaction the first time he takes the test is no assurance he will not react at a later date. ${ }^{64}$ Although severe reactions are very rare, given the controlled dosage of Nalline, the fact that Nalline may result in weekly attacks of nausea and vomiting to those who do react to the drug may, in itself, be sufficient to "shock the conscience" of the court. .5

It would be innaccurate, however, to base the entire attack against Nalline on its potential uncontrollable dangers. Certainly any court that reviewed this problem would want to inquire into the entire scope of Nalline testing in California. It must be remembered that to adopt a substantive due process test is to legislate. The court is essentially concerned with whether or not it approves of the substantive issue before it, and not necessarily concerned with finding any specific provision of the Constitution upon which that activity may be struck down. In Skinner v. Oklahoma ${ }^{56}$ the Court struck down a provision allowing sterilization of larcenists who had two previous felony convictions. The ground for striking down the statute was that it violated the equal protection clause. The Court stated that it demied equal protection because larcenists could be sterilized but embezzlers could not. Normally a statute is not unconstitutional for being underinclusive, because the legislature may attack the problem one step at a time. Basing Skinner on equal protection grounds was, of course, attenuated. The logical conclusion of the Court's result in Skinner is that although the state cannot sterilize larcenists alone, it could sterilize both larcenists and embezzlers. The Court did not intend that at all. As in Robinson, the Court was condemning a state criminal statute and finding a constitutional provision to legitimize its interference with the legislative process.

Given the fact that the Court does in fact legislate in the area of criminal substantive law, as reflected by both the Robinson and Skinner decisions, it is necessary to outhne the legislative policies of Nalline testing to determine whether it shall be continued in California, at least as presently administered by the Department of Corrections. Even if, upon review of the entire problem of Nalline, the courts decide that it is constitutionally permissible, the foregoing analysis of the Nalline

53 Terry Interview, supra note 24.

64 See Recomamended Procedures, supra note 15, at 2-4.

${ }^{55}$ Some judges are easily shocked. Justice Douglas, writing the dissent in Breithantpl, stated: "If the decencies of a civilized state are the test, it is repulsive to me for the police to insert needles into an unconscious person ... whether they find the person unconscious, give him a pill which puts him to sleep, or use force to subdue him." 352 U.S. 432,444 (1957).

56 316 U.S. 535 (1942). 
process might at least suggest that the legislature abohsh Nalhne testing in California.

\section{III}

\section{POLICY OBJECTIONS TO THE NALLINE TEST}

Proponents of Nalline testing do not view it as a panacea. They reahize that Nalline is not a cure, but merely a method of control. As such, they find Nalline has certain advantages over other attempts to control narcotics use. A positive result occurs in the presence of even small quantities of narcotics, and false positives are extremely rare..$^{57}$ The results are available immediately, and there is little chance of misidentification..$^{58}$ Nalline provides frequent contact between the addict and the physician. ${ }^{59}$ It is quick and easy to perform; ${ }^{60}$ it is comparatively inexpensive. ${ }^{.1}$

However, Nalline does have certain disadvantages. It requires an injection which must be administered by a trained physician. ${ }^{62}$ It necessitates the congregation of addicts at the test centers; it may result in undesirable side effects. ${ }^{63}$ It does not indicate which narcotic was used; it will not test out for all drugs. ${ }^{84}$ Nalline itself may make a person "high" even if he is not using any narcotics. ${ }^{65} \mathrm{It}$ is possible to circumvent the test by taking counteracting drugs. However, even if we assume that Nalline does have certain advantages, they are far outweighed by the disadvantages.

\section{A. The Need for a Licensed Physician}

The requirement of a trained physician to inject the Nalline severely himits the test's flexibility. The test must be performed at regularly scheduled clinics where a doctor is available. Nalhine testing is inexpensive only so long as the doctor can administer enough tests within a one hour period to make it financially acceptable. The doctor receives two dollars for each Nalline test which he performs. The cost of arranging a surprise Nalline test for one or a few parolees would be prohibitive. It is im-

67 Dr. Guy Turgeon, Statement Before the Cal. Assembly Interim Comm. on Criminal Procedure 12 (Los Angeles, Cal., Aug. 11, 1966) [hereinafter cited as Turgeon].

58 Id.

50 It is hoped that contact with a physician will indicate to the parolee that he is being treated rather than being spied upon.

60 Turgeon, supra note 57 , at 12 .

61 The cost of Nalline testing in Alameda is approximately $\$ 2$ per man.

62 Turgeon, supra note 57 , at 12 .

63 See text accompanying note 26 supra.

04 See text accompanying notes 10-12 supra.

65 Interview with Dr. David Smith, Haight-Ashbury Medical Clinic, San Francisco, Cal., Oct. 13, 1967. 
probable that a licensed doctor would take the time to administer a Nalline test unless he could be assured that he would make as much as he could in private practice. To assure a physician this sort of return would price individual Nalline testing beyond the bounds of administrative economy of scale. An alternative approacli would be to keep a salaried doctor on call at all times to administer the test. However, the cost of maintaining the doctor would still outweigh its feasibility.

In Alameda County, the Nalline Clinic is held at the County Health Department from 12:00 to 1:00 p.m. every Monday, from 5:00 to 6:00 p.n1. every Tuesday through Thursday, and Saturday niornings. A parolee's parole agent determines low many times a month he shall test (usually once a week for the first three months, then every other week), and the agent schedules the tests for the parolee on the same day each week. This is done so the agent can easily get in touch with the parolee if he so desires by meeting him at the chinic, and so the parolee can schedule his work hours not to interfere with the test.

In theory, the scheduled test hours allow the parolee to fulfill his parole conditions and at the same tine maintain gainful employment. Unfortunately, the realities of economic hife do not support the theory. It is difficult enough to get a job even without a prison record; with one, it is alnost impossible. Even employers who are willing to take parolees usually will not take addicts because they are too unstable. ${ }^{60}$ Therefore, most addicts do not reveal their past use when applying for jobs. Since the employer does not know the parolee was involved in narcotics, it is difficult to get the time off to take a Nalline test. If the parolee uses his lunch hour on Monday, he risks returning to the job late. If he tests at the evening climic, he must get off work early. Since many parolees do not have cars or do not drive as a condition of parole, they must rely on public transportation to get to the clinic. Because of this, many must leave for the chic at least one hour ahead of time.

Because most parolees are not skilled individuals, they are easily replaced on the job. As a result, a parolee who gets a job without telling his employer about Nalline has a difficult time explaining the necessity for time off and soon finds himself out of a job. The parolee who discloses his position cannot get the job in the first place because the employer can find a nonaddict who does not require special privileges to do the job. $^{67}$

The end result is that the added burden of Nalline lessens the

60 Interview with Mrs. Marion Hanaran, liaison for the parole division at the State Department of Employment in Southern Alameda County, in Oakland, Cal., Aug. 17, 1967. 67 Id. 
parolee's chances of successfully completing his parole. He gets depressed and resentful and soon finds himself back in the same environment that first led him to drugs. An obvious solution to this problem seems to be to conduct the Clinic at a later hour to enable parolees to work and still attend the clinic. If the purpose of Nalline is to rehabilitate the addict, it should be given at a time that would be most rehabilitative. Therefore, it must be assumed that the Department of Corrections either has considered this alternative and rejected it for some administrative reason or that it has not yet considered it at all.

\section{B. Congregation of Addicts}

A more significant problem fostered by the scheduled Nalline Clinic is the congregating of addicts. The Clinic is held during hours that the normal Health Department is closed. Therefore, there are only parolled and probationed narcotics users at the Clinic. Since they come the same day of the week, the same groups are always together. They have only two things in common-prison and history of drug use. Because on the average fifteen to thirty people are scheduled to take the test at a given hour, it is extremely difficult if not impossible to keep them isolated. If a parolee is trying to go straight by disassociating himself from former friends, pushers and addicts, Nalline makes it more difficult. At the Clinic he hears the others talk about circumventing Nalline and staying on drugs, and he learns where to buy drugs if he weakens. Addicts are not known for their strong sense of self-assurance and will power. Any progress an individual makes on his own toward going straight may soon be dissipated during one hour at the Clinic.

\section{Impossibility of Identifying Narcotic Used}

Nalline can only determine whether narcotics are being used; it cannot determine what narcotic is being used. Although this may not be important in determining whether to send parolees back to prison, it may be important if he is to be helped and rehabilitated. Narcotics use is usually an indication of other problems. ${ }^{68}$ If the parolee is using a drug he has never used before, it may be an indication that he is facing a new crisis, rather than falling back to an old need. If the agent has this information before him, he may be able more accurately to determine whether this person would benefit more by returning to prison or by remaining on the street.

08 Interview with Dr. J. Wald, psychiatrist for the Department of Corrections, Parole and Community Sęrvices Division, Oakland District, in Oakland, Cal., Aug. 9, 1967. 


\section{Inability to Detect all Drugs}

Nalline is only effective on a limited amount of drugs, mainly those in the opium family. ${ }^{69}$ Yet, this fact is not commonly known by those parole agents who make the decision to test a parolee. In fact, the whole purpose of the Nalline test is often misunderstood by the agents. To some agents, all drug users require Nalline testing. There are no differentiations; there is no distinction between a heroin shooter and a marijuana smoker. ${ }^{70}$

Because the majority of narcotics convictions today are connected with marijuana ${ }^{71}$ it seems that unless the Parole Division makes it clear who shall be tested, the Clinic may in fact be doing the community and the parolee a great disservice. Certainly the state has no interest in testing individuals that are on drugs that Nalline cannot detect. Furthermore, if marijuana users go to the Clinic, they will be continually confronted with the opportumity to graduate to the addictive drugs.

\section{E. Nalline May Itself Produce “"High" Sensation}

Probably the most damning thing about Nalline is that it can give the parolee a "high" sensation similar to that experienced by taking drugs. ${ }^{72}$ Nalline is similar to a narcotic in its effect on the user who is not taking any narcotics. Certainly the high is not as intense or as long lasting as a real fix but, psychologically, it may be more damaging. The social outlook for a narcotics addict is bleak at best. The frustrations of trying to make it on the street are usually more than the parolee can handle without resorting to drugs to alleviate the pressures. If, in fact, the parolee has managed to stay clean by himself, this will power is easily destroyed by Nalline. Once the addict experiences the "high" created by Nalline, it becomes all too easy for him to lose his will power and resort to drug use again, so he can inaintain the higln feeling with which Nalline has reunited him.

Of course, all parolees who experience the "high" do not resort to drugs. Some find that weekly injections of Nalline are sufficient to satisfy their craving for drugs. ${ }^{73}$ Certainly Nalline should not be allowed to be

${ }^{69}$ See text accompanying note 9 supra.

70 While working as an intern for the Parole Division, Oakland District, during the summer of 1967 , this writer discovered that three parole agents had marijuana users on a program of Nalline Testing. When asked the reason for testing these parolees, the agents stated that they always tested all narcotics users. Upon learning that Nalline would not detect marijuana, they took the parolees off Nalline.

71 California Dep't of Justice, Buread of Cromtnal Statistics, Drdo Arrests and Dispositions In CAIIFORNIA 14 (1962).

72 See text accompanying note 26 supra.

73 Interview with Ike Rivers, Parole Supervisor, San Francisco District, in San Françisco, Cal., Aug. 7, $196 \%$. 
used as a substitute for illegal narcotics. Such a practice only defers readdiction until after the expiration of parole. The purpose of Nalline should be to force the parolee to do without drugs and still adjust to the society in which he now must exist.

If Nalline either produces a" high" which psychologically encourages parolees to revert to drugs or merely provides them with a crutch to abstain from drugs during their parole, its use by the Department of Corrections is unwarranted. The expending of funds to aid in the readdiction of parolees, whether presently or at the termination of parole, cannot be considered reasonable.

\section{F. Circumventing the Test}

It is claimed that Nalline testing prevents readdiction because it detects use. But the fact that Nalline can prevent use during parole is irrelevant. If Nalline will encourage use after parole, it has failed to meet the purpose it was designed to effectuate.

The Alameda County Probation Department utilizes Nalline in the same manner as does the Parole Division. It considers Nalline to be an effective control device because in the first year in which the Nalline Clinic was utilized, thirty-one percent of those tested indicated use of narcotics, and now only about four percent of those tested have positive results. ${ }^{74}$ These statistics may not accurately reflect this conclusion. Once those required to submit to Nalline realized that the results were accurate, they merely failed to show up for the test when they had been using drugs. If the agent found the parolee before the effects of the drug wore off (two to three days), a urine specimen would immediately be taken and tested. In the majority of cases the urinalysis was positive, indicating use. So, even though Nalline positives went down, it did not accurately reflect the use of narcotics in the Oakland area.

Another, and more important, reason that Nalline does not control use of narcotics is that the test can be circumvented. If the Nalline results are positive, it is a good indication of use. But if the results are negative, it does not indicate abstinence. Nalline is antagonistic to the presence of narcotics in the system, which is indicated by a chemical imbalance within the body itself. If one drug is taken to counteract another drug in the system, the imbalance is corrected, and Nalline has no substance with which to react antagonistically. Therefore, heroin users (heroin being a central nervous system depressant) take methedrine (a central nervous system stimulant) to counteract the heroin. By the time the parolee arrives at his regularly scheduled test the nethedrine has taken

74 Alameda County Probation Department, Nalline as an Aid in Probationary Supervision of Narcotic Offenders, Three Years' Retrospect 1 (1959). 
effect, and the Nalline results are negative. Of course, the procedure to beat the test is not always effective. It is difficult to assess the amount of narcotic in the system when it is desired to counteract its effect; therefore, it is also difficult to judge the amount of the "opposite" drug needed to reverse the effect, or return the system to a balanced state. Too little or too much will result in a positive Nalline test. ${ }^{75}$ But, the years of experimenting by parolees have paid off in a fairly precise method of circumventing the test.

\section{CONCLUSIONS AND ALTERNATIVES}

The inadequacies of the Nalline program necessitates its abolition. This can be done either by a court finding that Nalline testing is a violation of the parolees' due process rights, or through a legislative policy change. Abohtion of Nalline testing does not mean abolition of a narcotics control program. To be sure, some control system is needed. But, hopefully, this program would be both more effective and more humane.

Criticism of Nalline comes not only from the outside. Many parole agents have recognized Nalline's shortcornings and have abandoned regular Nalline testing, substituting a program of testing by surprise urinalysis. ${ }^{78}$ If Nalline is abohshed in Cahifornia, it should be replaced by a full scale program of urine testing.

Urinalysis can do everything Nalline is supposed to do. It can do it for the same price (approximately two dollajs per test), and without the unpleasant side effects. ${ }^{77}$ If urinalysis is employed, there is no need for the parolee to travel any great distance; he would not have to take time off from work to attend the clinic. No doctor is needed to give the test. The urine sample could be taken by the agent when he contacts the parolee; the agent could then take the sample to the laboratory for testing. Because the sample can be taken at the parolee's home, the congregation of addicts can be avoided. The urine test will detect most narcotics, and it cannot be circumvented by taking other drugs. It will indicate the precise drug that was taken; there are no unfavorable effects and the parolee will experience no "higlh" seusation.

One objection to the urine test is that the results are not immediately available; a minimum of two days elapses before results are obtained. But if the purpose of the test is to control addiction and not merely to get narcotics convictions, such delay is insignificant. Certainly once

75 Terry Interview, supra note 24.

76 See generally Parker, Hine, Nomof \& Elliot, Urine Screening Tcchniques Employed in the Detection of Users of Narcotics and Their Correlation with the Nalorphine Test, $11 \mathrm{~J}$. FOR. Scr. 152 (1966).

77 Id. at 165. 
this test is established and parolees realize they cannot circumvent it, they will be more likely to abstain from drugs. If drugs lrave been used, the test will be positive; a user would lrave to violate parole before the results were received to avoid being returned to prison. Past experience at the Oakland Parole Office indicates that parolees do not violate parole after a urinalysis when they had taken drugs prior to the test, because the chance of being caught and returned to prison for a long term is very higl.

The foregoing analysis indicates that urine testing would be at least as effective in controlling narcotic use among parolees as any other approacli yet implemented by the Department of Corrections. Nalline has failed to provide an adequate and humane vehicle of control and rehabilitation. Therefore even if Nalline is found to be constitutionally permissible, as a matter of policy it is self-defeating and should be replaced by a umform program of urinalysis.

Steven H. Goldfarb 